\title{
TRIP13 Gene
}

National Cancer Institute

\section{Source}

National Cancer Institute. TRIP13 Gene. NCI Thesaurus. Code C118328.

This gene is involved in meiotic recombination. 